\title{
Role of Repetitive Nerve Stimulation, Serum Creatine Phosphokinase and Lactate Dehydrogenase in Early Prediction of Respiratory Failure in Acute Organophosphorus Poisoning
}

\author{
Samah A. Elnagdy and Nahed Shehta ${ }^{1}$
}

\footnotetext{
${ }^{1}$ Departments of Forensic Medicine \&Clinical Toxicology and Neurology*, Faculty of Medicine, Zagazig University, Al Sharqia, Egypt.
}

All rights reserved.

\begin{abstract}
The most serious complication associated with acute organophosphorus (OP) poisoning is intermediate syndrome (IMS) due to the possibility of developing respiratory failure. Abnormalities observed in repetitive nerve stimulation (RNS) may help to assess severity of IMS and eventually help to predict the cases which are more liable to develop respiratory failure. Also, some researchers suggested that IMS is associated with rhabdomyolysis which is followed by a rise in creatine phosphokinase (CPK) and lactate dehydrogenase (LDH) serum levels. The aim of this work was to study the role of RNS and serum levels of CPK and LDH in predicting respiratory failure in acute OP poisoning. The study was carried out on 55 patients who were diagnosed as acute OP poisoning and admitted at Poison Control Center, Zagazig University Hospitals in the period from April 2013 to June 2014. The patients were subjected to estimation of serum pseudocholinesterase, CPK and LDH levels at time of admission and repeated at the $4^{\text {th }}$ day of poisoning. Also, RNS test at 3 hertz (HZ) frequency was done to all patients at 2 nd, 3 rd and $4^{\text {th }}$ day of poisoning (the period at which IMS is expected). At the end of the study, it was found that the patients who developed respiratory failure showed significant increase in decrement response recorded by RNS and in serum CPK level. On the other hand, there was non-significant difference between patient who developed respiratory failure and those who didn't as regard serum LDH level. It was concluded from this study that, RNS test at $3 \mathrm{HZ}$ and serum CPK level can be used as early predictors of respiratory failure in acute OP poisoning and it's recommended to use them especially in patients who are clinically diagnosed as severe poisoning at time of admission.
\end{abstract}

Keywords Organophosphorus, IMS, CPK, LDH, RNS, decrement response.

\section{Introduction}

$\mathrm{I}$ $\mathrm{n}$ developing countries, there is a wide spread use of organophosphorus (OP) insecticide compounds which has been associated with a significant increase in incidence of poisoning with these agents. This is attributed mainly to their easy availability, indiscriminate handling, storage and lack of knowledge about the serious consequences of poisoning with such insecticides (Makwava et al., 2012).

Organophosphorus insecticides are irreversible inhibitors of acetylcholinesterase (AchE) enzyme. They inhibit both true cholinesterase and pseudocholinesterase (PchE) activity, which result in accumulation of acetylcholine (Ach) at synapses. The clinical manifestations are due to excess Ach at muscarinic and nicotinic receptors with initial stimulation, and then exhaustion of cholinergic synapses. There are three phases in acute OP poisoning. Acute cholinergic crises (first 48 hours), intermediate syndrome (IMS) (24-96 hours after poisoning) and delayed polyneuropathy. The acute cholinergic phase usually passes off within 48 hours but complete clinical recovery may take up to one week (Abdollahi and Karami-Mohajeri, 2012).

Some Deaths from acute OP poisoning occur at or soon after admission (within the first 24 hours of 
poisoning) during the acute cholinergic crisis. Most of such deaths result from acute respiratory failure due to central respiratory depression or from bronchospasm and bronchorrhea. Early and rapid atropenization is a priority during this phase. Complications of pre-hospital respiratory arrest and unconsciousness, such as aspiration and anoxic brain damage, cause further deaths during the in-patient stay (Eddleston et al., 2005).

On the other hand, there are deaths which occur days after admission after the patients have been stabilized and treated with oximes and atropine. These deaths are attributed to sudden respiratory arrest in which IMS is implicated. Unfortunately, in the hospitals with poor resources, facilities do not exist for poisoned patients to be routinely admitted to an ICU for close observation (Basnyat, 2000 and Michael et al., 2006)).

The role of oximes in the management of OP poisoning is controversial. Although Cherian et al. (1997) suggest that oximes don't favorably affect the outcome based on several parameters including total atropine requirement and the duration of ventilation and hospitalization, Singh et al. (1998) noted that obidoxime administration produced dramatic neurophysiologic improvement on neuromuscular transmission when administered within the first 12 hours with no improvement or even worsening when it was administered after 24 hours of poisoning.

Intermediate syndrome (IMS) is a syndrome of muscular paralysis occurring in conscious patients 24-96 $\mathrm{h}$ following ingestion of an organophosphorus insecticide (De Bleecker, 1995; Karalliedde et al., 2006 and Jayawardane et al., 2008). Muscle weakness affects predominantly the proximal limb muscles and those supplied by the cranial nerves including facial muscles. Although IMS is a very serious complication of acute organophosphorus poisoning due to the possibility of developing respiratory failure, its pathophysiology is not clearly understood (Karalliedde et al., 2006).

Many studies have been carried out to investigate the diagnostic and prognostic value of serum pseudocholinesterase level in organophosphorus (OP) poisoning and their relationship with intermediate syndrome. Most of these studies have shown that though serum pseudocholinesterase (PchE) level can be used as a diagnostic marker for OP poisoning, its role in predicting outcome is minimal (Yun et al., 2012).

Some researchers suggested that OP-labelled albumin, blood $\beta$-glucuronidase and paraxonase status can be used as very reliable markers for both diagnosis and prognosis of acute OP poisoning. The problem lies in that theses assays are costly and require specialized laboratories. So, cheap, available and easily measurable biomarkers having prognostic and predicting values are needed (Agarwal et al., 2006).

Experimental studies proved that rhabdomyonecrosis occur in animals after poisoning by OP compounds and some human studies revealed elevations in serum creatine phosphokinase (CPK) and lactate dehydrogenase (LDH) levels following acute OP poisoning and attributed that to muscle injury (John et al., 2003).

Repetitive nerve stimulation (RNS) is a variant of the nerve conduction study where electrical stimulation is delivered to a motor nerve repeatedly several times per second. By observing the change in the muscle electrical response after several stimulations, a physician can assess for the presence of a neuromuscular junction disease. A decrement response (a smaller and smaller muscle response with each repetitive stimulus) is abnormal and indicates NMJ dysfunction (Mills, 2005).

Repetitive nerve stimulation (RNS) depends on applying a series of small electrical shocks to certain nerves and the responses in the muscles innervated by these nerves are recorded. The percentage of decrement response which is the decrease in amplitude of the fifth to the first electrical muscle response is directly correlated with the impairment in nerve transmission (Yang et al., 2001).

A review of some clinical and experimental electrophysiological studies in IMS shows that subclinical electrophysiological abnormalities are common and progressive. Repetitive nerve stimulation (RNS) has been validated as one of most useful electrophysiological tests in the evaluation of patients with suspected neuromuscular junction disorder including IMS which complicates OP poisoning (Paulo et al., 2010).

\section{Aim of the study}

This study was carried out to study the role of the neurophysiological technique repetitive nerve stimulation (RNS) and serum levels of CPK and LDH in predicting respiratory failure in patients with acute $\mathrm{OP}$ poisoning, so that precautions for appropriate management of those patients could be undertaken.

\section{Subjects and Methods Subjects}

This study is a prospective observational study conducted on 55 patients diagnosed as acute organophosphate poisoning and admitted to Poison Control Center, Zagazig University Hospitals in the period between April 2013 and June 2014.

Informed written consent was obtained from all the patients who participated in the study or from their accompanying relatives. This study was approved by Ethical Committee of Faculty of Medicine, Zagazig University.

\section{Methods}

\section{Inclusion Criteria}

- History of exposure to an organophosphate insecticide either by oral ingestion, inhalation or by dermal exposure.

- Admission within 24 hours of exposure to OP (Pradeepa et al., 2012 and Kavya et al., 2012).

- Characteristic cholinergic and nicotinic manifestations of OP poisoning

- Reduced level of serum pseudocholinesterase level. 
Exclusion Criteria

- Patients with respiratory failure who are on mechanical ventilation due to inability to transfer from the intensive care unit (ICU) to the neurology department.

- Presence of factors that may reduce pseudocholinesterase level other than OP insecticides as age $<15 \mathrm{y}$, pregnancy, liver disease or cancer (Aaron and Howland, 2006)

- Presence of factors that may increase serum $\mathrm{CPK}$ or LDH levels which include the following:

- Patients who had history of any kind of illnesses like myopathy, chronic renal disease, epilepsy, myocardial infarction, myocarditis,malignancy or autoimmune diseases (Hsiao et al., 2008).

- Patients who are on prior medications like statins, fibrates, aspirin, anticoagulants, frusemide, and dexamethasone (Magalhaes, 2005).

\section{Methods}

After carefully considering the inclusion and exclusion criteria, patients were subjected to:

\section{Clinical evaluation}

Complete history taking including mode of poisoning, the time elapsed between poisoning and hospitalization, amount taken (in case of ingestion) and type of the organophosphorus compound

Clinical examination for symptoms and signs of cholinergic and nicotinic manifestations including miosis, excessive salivation, lacrimation, bronchial secretions, gastrointestinal manifestations, urinary incontinence, fasiculations and convulsions. A scale known as Peradeniya Organophosphorus Poisoning Scale (POP scale) proposed by Senanayake et al in 1993, was used to assess clinical severity of poisoning. This scale can grade severity without laboratory investigations. It also does not rely on patient cooperation and hence can be applied to all groups of patients without the need of their cooperation. POP scale ranks the severity of poisoning using five clinical signs (pupil size, heart rate, respiratory rate, level of consciousness, and seizures). Each sign is graded on a scale from 0 to 2 , with an additional point given for those that seize. According to POP scale, clinical severity was classified into mild poisoning (score 0-3), moderate poisoning (score 4-7), severe poisoning (score 8-11) [Table 1]. The score was obtained at initial presentation before doing any medical intervention.

\section{2-Laboratory investigations:}

A venous blood sample $(5 \mathrm{ml})$ was collected in plain tube under aseptic precautions. Blood was allowed to clot, serum was separated by centrifugation and used for the analysis of following parameters:

Estimation of serum pseudocholinesterase (PchE) level by the calorimetric method described by
Waber (1966) (normal level 1900-3800 U/L). The initial measurement and that at $4^{\text {th }}$ day after poisoning were reported in this study.

Estimation of serum creatine phosphokinase (CPK) and serum LDH levels by the spectrophotometric method described by Rosalki (1967) and Morgenstern et al.(1965) respectively (The normal value of serum CPK is $50-176 \mathrm{IU} / \mathrm{L}, \mathrm{LDH}$ is $105-333 \mathrm{IU} / \mathrm{L}$ ). Serum levels of $\mathrm{CPK}$ and $\mathrm{LDH}$ were measured at admission time and repeated at the $4^{\text {th }}$ day of poisoning. The decision of estimating serum pseudocholinesterase, CPK and LDH levels at $4^{\text {th }}$ day following acute OP poisoning was because at this time, IMS (24-96 hours) is expected to either resolve with clinical improvement of the patient or there will be deterioration of IMS with possible development of respiratory failure (Lee and Tai, 2001).

\section{3- Neuroelectrophysiological study using RNS:}

24 hours after OP poisoning, the patients were submitted to a neurophysiological study in the form of repetive nerve stimulation for three successive days (i.e at the 2nd, $3^{\text {rd }}$ and $4^{\text {th }}$ day after poisoning) to evaluate intermediate syndrome which occur 24-96 hours after acute OP poisoning (De Bleecker, 1995; Karalliedde et al., 2006 and Jayawardane et al., 2008). RNS was carried out in the present study using Nicolet electromyography machine (non portable) ((Fig. 1) according to the guidelines for repetitive nerve stimulation recording mentioned by Stilberg and Sanders (1981) which included the following:

-A peripheral nerve is electrically stimulated and the amplitude of the compound muscle action potential (CAMP) is recorded at rest and after a short voluntary activation.

-The stimulation frequency is $3 \mathrm{HZ}$ and the number of stimuli is $9-10$.

-The result is reported as the difference in amplitude of the CAMP between stimulation one and five (in \%).

Spinal accessory nerve as a proximal motor nerve (supplying trapezius muscle) and facial nerve (supplying nasalis muscle) were chosen for performing repetitive nerve stimulation test. These two nerves were chosen for performing RNS as proximal limb muscles and muscles supplied by cranial nerves including facial muscles (innervated by facial nerve which is cranial nerve VII) are the most affected muscles in IMS. The technique was done by using surface disk electrodes to record the CAMP amplitude. RNS testing of spinal accessory nerve was carried out by placing the active electrode over the proximal part of the trapezius muscle and the stimulator over the spinal accessory nerve, just behind the sternocleidomastoid muscle. On studying the facial nerve by RNS, the active electrode was placed on the nasalis muscle and the stimulator over the facial nerve. A train of nine to ten supramaximal stimuli were delivered at $3 \mathrm{~Hz}$ frequency. The ratios of the amplitude of the fifth CAMP response to the first response were noted. This ratio effectively measure the percentage of decrement response (\%). A CMAP decrement of $10 \%$ or 
more is considered a significant one. Manual immobilization of patient had been considered to minimize the artifacts.

4- Follow up of all patients with clinical observation until the patient is either cured and discharged or deteriorate and develop respiratory failure with the need to be mechanically ventillated .

\section{Data analysis}

The Statistical Package for the Social Sciences (SPSS) program, version 11.01 was used for data analysis. Oneway ANOVA test was used when more than two groups with parametric data were to be compared, while Kruskal-Wallis test was used when nonparametric data were compared. Correlation between variables was done using correlation coefficient " $r$ ".Values were considered statistically significant if $\mathrm{P} \leq 0.05$ and highly significant if $\leq 0.001$ (Norusis, 1997).

\section{Results}

The age of the patients participated in the study ranged from 17-52 years (mean age $=26.5$ years). Most patients $(83.6 \%)$ gave history of living in rural areas, while only $16.4 \%$ were living in urban areas. The socioeconomic status of the patients was assessed using modified ElSherbini and Fahmy (1983) classification according to four parameters; education, occupation, income and crowding and it was found that most patients participated in the study were of low socioeconomic status $(81.8 \%)$ while $14.6 \%$ and $3.6 \%$ were of moderate and high socioeconomic status respectively. This study showed that the commonest organophosphorus compound encountered in poisoning was chlorpyrifos (41.8\%). Other OP compounds implicated in poisoning were malathion (29\%), parathion (23.7\%), propenophos and triazophos (5.5\%). Mode of poisoning was mainly suicidal $(85.5 \%)$ followed by accidental (10.9\%), while only $3.6 \%$ was homicidal. The patients included in the study were subdivided into mild $(\mathrm{n}=20)$, moderate(23) and severe(12) groups according to the criteria determined by POP scale (Fig.2).

There was a significant difference among patients with different clinical severities (as determined by POP scale) as regard initial pseudocholinesterase level $(p<0.05)$. On the other hand, there was non-significant difference between them 4 days after poisoning $(p>0.05)$ (Table 3). As regard mean values of serum CPK measured both at time of admission and 4 days after poisoning, there was a significant difference among patients with mild, moderate and severe poisoning $(\mathrm{p}<0.001)$ (Table 3).

Comparing the mean values of serum LDH levels among patients with mild, moderate and severe OP poisoning revealed non-significant difference neither at admission time nor at the $4^{\text {th }}$ day following poisoning (p>0.05) (Table 3).

At the end of the study, comparing the mean values of serum pseudocholinesterase measured at $4^{\text {th }}$ day of poisoning between patients who developed respiratory failure and those who showed complete recovery and discharged revealed non-significant difference $(\mathrm{p}>0.05)$ (Table 4).

On the other hand, there was a significant difference between patients who developed respiratory failure and those who didn't regarding serum CPK measured 4 days after poisoning $(p<0.001)$ (Table 4$)$.

Comparing mean values of serum LDH measured at $4^{\text {th }}$ day of poisoning revealed non-significant difference between patients complicated with respiratory failure and patients who escaped this complication ( $p>0.05)$ (Table 4).

There was a significant difference between patients with mild, moderate and severe OP poisoning as regard mean values of decrement response recorded by RNS of spinal accessory and facial nerves at $2^{\text {nd }}, 3^{\text {rd }}$ and $4^{\text {th }}$ day of poisoning $(\mathrm{p}<0.001)$ (Table 5, 6, 7).

In mild cases $(n=20)$, there was a progressive decrease in decrement response of spinal accessory nerve and facial nerve as recorded by RNS at $2^{\text {nd }}, 3^{\text {rd }}$ and $4^{\text {th }}$ day of poisoning. This was associated with clinical improvement and all mild cases were discharged (Table $5,6,7)$.

Regarding patients with moderate OP poisoning $(n=23), 21$ patients showed progressive decrease in decrement response of both spinal accessory and facial nerve recorded by RNS at $2^{\text {nd }}, 3^{\text {rd }}$ and $4^{\text {th }}$ day of poisoning together with clinical improvement and discharged one week after admission. Only 2 cases developed progressive increase in the percentage of decrement response (the decrement response was 25 , $27 \%$ (spinal accessory ) and 22, 26\% (facial nerve) at $2^{\text {nd }}$ day increased to $30,32 \%$ (spinal accessory) and 34, 37 $\%$ (facial nerve) at $3^{\text {rd }}$ day then to $35,38 \%$ (spinal accessory) and $38,40 \%$ (facial nerve) at 4 th day (Table $5,6,7)$. The increase in percentage of decrement response was associated with clinical deterioration and the 2 cases developed respiratory failure and needed mechanical ventillation (one case 2 days and the other case 4 days after the last RNS test)

Out of the 12 severe cases, 6 patients showed progressive increase in the severity of decrement response (range was $37-44 \%$ (spinal accessory) and 32$41 \%$ (facial nerve) at $2^{\text {nd }}$ day increased to $39-50 \%$ (spinal accessory) and $33-43 \%$ (facial nerve) at $3^{\text {rd }}$ day then to $41-55 \%$ (spinal accessory) and $39-52 \%$ (facial nerve) at $4^{\text {th }}$ day). All these patients developed respiratory failure 1-3 days later and needed mechanical ventilation. The remaining 6 cases showed progressive decrease in decrement severity (range was $15-33 \%$ (spinal accessory) and $16-27 \%$ (facial nerve) at $2^{\text {nd }}$ day decreased to 10 $25 \%$ (spinal accessory) and $10-13 \%$ (facial nerve) at $3^{\text {rd }}$ day and reached $8-17 \%$ (spinal accessory) and 5-9\% (facial nerve) at $4^{\text {th }}$ day) (Table 5, 6, 7). This decrease in decrement severity was associated with clinical improvement.

When the mean values of decrement response severity of both spinal accessory and facial nerve were compared between patients who developed respiratory failure and those who didn't at the $4^{\text {th }}$ day of poisoning, a 
significant difference was found with the patients who developed respiratory failure showed the higher decrement response $(\mathrm{p}<0.001)$ (Table 8).

By studying the correlation between the biochemical parameters measured at the $4^{\text {th }}$ day of poisoning and severity of decrement response measured at $4^{\text {th }}$ day, it was found that there was a strong positive correlation between serum CPK level and severity of decrement response (of both spinal accessory and facial nerve) $(\mathrm{p}<0.001)$ (Table 9) (Fig. 3, 4).

On the other hand, there was no correlation between serum LDH level and severity of decrement response (of spinal accessory and facial nerve) assessed at $4^{\text {th }}$ day of poisoning ( $\left.>>0.001\right)$ (Table 10) (Fig. 5, 6).

Table (1): The Peradeniya organophosphorus poisoning scale (Senanayake et al., 1993)

$\begin{array}{lll}\text { Parameters } & \text { Criteria } & \text { Score } \\ \text { Pupil size } & \geq 2 \mathrm{~mm} & 0 \\ & <2 \mathrm{~mm} & 1 \\ & \text { Pinpoint } & 2 \\ \text { Respiratory rate } & <20 / \mathrm{min} & 0 \\ & \geq 20 / \mathrm{min} & 1 \\ & \geq 20 / \mathrm{min} \text { with central cyanosis } & 2 \\ \text { Heart rate } & >60 / \mathrm{min} & 0 \\ & 41-60 / \mathrm{min} & 1 \\ \text { Fasciculation } & <40 / \mathrm{min} & 2 \\ & \text { None } & 0 \\ \text { Level of } & \text { Present, generalized/continuous } & 1 \\ \text { consciousness } & \text { Both generalized and continuous } & 2 \\ & \text { Conscious and rationale } & 0 \\ \text { Seizures } & \text { Nompaired response to verbal commands } & 1 \\ & \text { Absent } & 2 \\ & \text { Present }\end{array}$

Note: $0-3$, mild poisoning; 4-7, moderate poisoning; $8-11$, severe poisoning

Table(2): Demographic profile of patients participated in the study $(n=55)$

\begin{tabular}{|l|l|}
\hline Parameter & Frequency (\%) \\
\hline Sex & \\
\hline Female & $33(60 \%)$ \\
\hline Male & $22(40 \%$ \\
\hline Residence & \\
\hline Rural & $46(83.6 \%)$ \\
\hline Urban & $9(16.4 \%)$ \\
\hline Socioeconomic status & \\
\hline Low & $45(81.8 \%)$ \\
\hline Moderate & $8(14.6 \%)$ \\
\hline High & $2(3.6 \%)$ \\
\hline OP compound included & \\
\hline Chlorpyrifos & $23(41.8 \%)$ \\
\hline Malathion & $16(29 \%)$ \\
\hline Parathione & $13(23.7 \%)$ \\
\hline Others(Propenophos, triazophos) & $3(5.5 \%)$ \\
\hline Mode of poisoning & \\
\hline Suicidal & $47(85.5 \%)$ \\
\hline Accidental & $6(10.9 \%)$ \\
\hline Homicidal & $2(3.6 \%)$ \\
\hline Severity of poisoning (POP scale) & \\
\hline Mild & $20(36 \%)$ \\
\hline Moderate & $23(42 \%)$ \\
\hline Severe & $12(22 \%)$ \\
\hline
\end{tabular}


Table(3): Comparison between serum levels of pseudocholinesterase (PchE) (U/L), Creatine phosphokinase (CPK) (IU/L) and lactate dehydrogenase (LDH) (IU/L) measured at time of admission and at $4^{\text {th }}$ day of poisoning according to clinical severity of the studied patients

\begin{tabular}{|c|c|c|c|c|c|c|c|}
\hline & \multirow{2}{*}{\multicolumn{3}{|c|}{$\begin{array}{l}\text { Classification of patients according to clinical severity (as } \\
\text { determined by POP scale) }\end{array}$}} & \multicolumn{2}{|c|}{ ANOVA test } \\
\hline & & & & & & \multirow{2}{*}{$\mathbf{F}$} & \multirow{2}{*}{$\mathbf{P}$} \\
\hline & & & Mild & Moderate & Severe & & \\
\hline \multirow{2}{*}{ PchE(U/L) } & Initial & \multirow{6}{*}{ 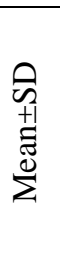 } & $905.5 \pm 67.4$ & $698.3 \pm 53.9$ & $371.8 \pm 75.8$ & 260.3 & $<0.001 * *$ \\
\hline & $4^{\text {th }}$ day & & $2020.7 \pm 408.4$ & $1956.5 \pm 395.1$ & $1681.7 \pm 353.2$ & 3.57 & 0.06 \\
\hline \multirow{2}{*}{$\begin{array}{c}\text { CPK } \\
\text { (IU/L) } \\
\end{array}$} & Initial & & $164.9 \pm 53.1$ & $369.7 \pm 72.5$ & $647.7 \pm 132.4$ & 136.2 & $<0.001 * *$ \\
\hline & 4thday & & $120.5 \pm 47.7$ & $192.9 \pm 139.6$ & $452.2 \pm 214.7$ & 16.5 & $<0.001 * *$ \\
\hline \multirow[t]{2}{*}{ LDH(IU/L) } & Initial & & $322.7 \pm 121.7$ & $467.9 \pm 298.6$ & $498.6 \pm 314.5$ & 2.9 & 0.06 \\
\hline & $4^{\text {th }}$ day & & $310.7 \pm 110.6$ & $397.9 \pm 150.6$ & $416.6 \pm 213.5$ & 2.6 & 0.08 \\
\hline
\end{tabular}

U//L: Unit per liter, IU/L: International unit per liter, P>0.05: Non-significant, $P<0.001$ : Significant **: Significant

Table(4):Comparison between patients who developed respiratory failure and those who didn't regarding serum levels of pseudocholinesterase (PchE) (U/L), Creatine phosphokinase (CPK) (IU/L) and lactate dehydrogenase (LDH) (IU/L) measured at $4^{\text {th }}$ day of poisoning

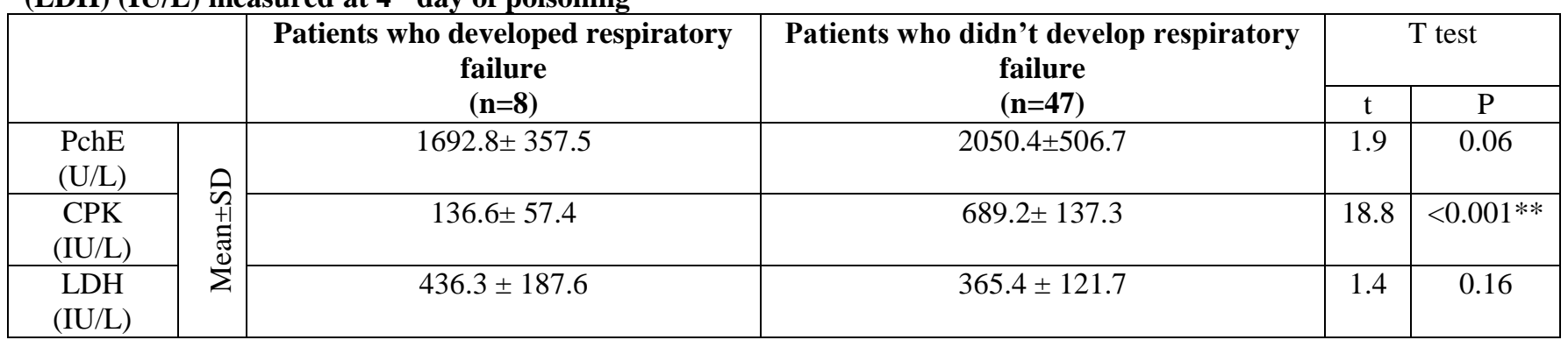

U//L: Unit per liter, IU/L: International unit per liter, P>0.05: Non-significant, $P<0.001$ : Significant **: Significant

Table (5): Percentage of decrement response (\%) as measured by repetitive nerve stimulation of spinal accessory nerve and facial nerve in patients with $O P$ poisoning at $2^{\text {nd }}$ day of poisoning

\begin{tabular}{|c|c|c|c|c|c|c|c|c|c|c|}
\hline \multirow{3}{*}{$\begin{array}{l}\text { Percentage } \\
\text { of } \\
\text { decrement } \\
\text { response } \\
(\%) \text { at } 4 \text { th } \\
\text { day after } \\
\text { admission }\end{array}$} & \multirow{2}{*}{\multicolumn{6}{|c|}{$\begin{array}{l}\text { Groups of the patients according to clinical severity as } \\
\text { determined by POP scale }\end{array}$}} & \multicolumn{4}{|c|}{ Kruskall-Wallis test } \\
\hline & & & & & & & & & & lue \\
\hline & \multicolumn{2}{|c|}{ Mild group } & \multicolumn{2}{|c|}{ Moderate group } & \multicolumn{2}{|c|}{ Severe group } & & & & \\
\hline \multirow[t]{2}{*}{ Mean \pm SD } & SpinalA & Facial & Spinal A & Facial & Spinal A & Facial & SpinalA & Facial & Spinal A & Facial \\
\hline & $6.7 \pm 2.7$ & $6.4 \pm 2.5$ & $16.9 \pm 5.8$ & $14.3 \pm 5.5$ & $31.2 \pm 11.7$ & $29.1 \pm 10.5$ & & & & \\
\hline $\begin{array}{l}\text { Median } \\
\text { (range) }\end{array}$ & $\begin{array}{l}6 \\
(2-11)\end{array}$ & $\begin{array}{l}7 \\
(3-10)\end{array}$ & $\begin{array}{l}16 \\
(8-25\end{array}$ & $\begin{array}{l}12 \\
(9-27)\end{array}$ & $\begin{array}{l}36 \\
(15-45)\end{array}$ & $\begin{array}{l}29.5 \\
(17-44)\end{array}$ & 37.67 & 41.42 & $<0.001 * *$ & $<0.001 * *$ \\
\hline
\end{tabular}

$P<0.001$ : Significant, ${ }^{* *}:$ Significant

Table (6): Percentage of decrement response (\%) as measured by repetitive nerve stimulation of spinal accessory nerve and facial nerve in patients with OP poisoning at 3rd day of poisoning

\begin{tabular}{|c|c|c|c|c|c|c|c|c|c|c|}
\hline \multirow{3}{*}{$\begin{array}{c}\text { Percentage } \\
\text { of decrement } \\
\text { response }(\%) \\
\text { at } 4 \text { th day } \\
\text { after } \\
\text { admission }\end{array}$} & \multirow{2}{*}{\multicolumn{6}{|c|}{$\begin{array}{l}\text { Groups of the patients according to clinical severity as } \\
\text { determined by POP scale }\end{array}$}} & \multicolumn{4}{|c|}{ Kruskall-Wallis test } \\
\hline & & & & & & & $\mathbf{K}$ & & & lue \\
\hline & \multicolumn{2}{|c|}{ Mild group } & \multicolumn{2}{|c|}{ Moderate group } & \multicolumn{2}{|c|}{ Severe group } & & & & \\
\hline \multirow[t]{2}{*}{ Mean \pm SD } & $\begin{array}{l}\text { Spinal } \\
\text { A }\end{array}$ & Facial & Spinal A & Facial & Spinal A & Facial & SpinalA & Facial & Spinal A & Facial \\
\hline & $5.1 \pm 1.2$ & $5.4 \pm 1.7$ & $15.9 \pm 6.6$ & $15.6 \pm 7.6$ & $29.3 \pm 15.7$ & $25.9 \pm 14.8$ & & & & \\
\hline $\begin{array}{l}\text { Median } \\
\text { (range) }\end{array}$ & $\begin{array}{l}5 \\
(2-8)\end{array}$ & $\begin{array}{l}5 \\
(2-8)\end{array}$ & $\begin{array}{l}15 \\
(8-32)\end{array}$ & $\begin{array}{l}14 \\
(7 .-37)\end{array}$ & $\begin{array}{l}32.0 \\
(12-50)\end{array}$ & $\begin{array}{l}24 \\
(10-46)\end{array}$ & 37.15 & 37.8 & $<0.001 * *$ & $<0.001 * *$ \\
\hline
\end{tabular}

$P<0.001$ : Significant, **: Significant 
Table (7): Percentage of decrement response (\%) as measured by repetitive nerve stimulation of spinal accessory nerve and facial nerve in patients with OP poisoning at 4th day of poisoning

\begin{tabular}{|c|c|c|c|c|c|c|c|c|c|c|}
\hline \multirow{3}{*}{$\begin{array}{l}\text { Percentage } \\
\text { of } \\
\text { decrement } \\
\text { response } \\
(\%) \text { at } 4 \text { th } \\
\text { day after } \\
\text { admission }\end{array}$} & \multirow{2}{*}{\multicolumn{6}{|c|}{$\begin{array}{l}\text { Groups of the patients according to clinical severity as } \\
\text { determined by POP scale }\end{array}$}} & \multicolumn{4}{|c|}{ Kruskall-Wallis test } \\
\hline & & & & & & & \multicolumn{2}{|c|}{$\mathbf{K W}$} & \multicolumn{2}{|c|}{ P value } \\
\hline & \multicolumn{2}{|c|}{ Mild group } & \multicolumn{2}{|c|}{ Moderate group } & \multicolumn{2}{|c|}{ Severe group } & & & & \\
\hline \multirow[t]{2}{*}{ Mean \pm SD } & $\begin{array}{l}\text { Spinal } \\
\text { A }\end{array}$ & Facial & Spinal A & Facial & Spinal A & Facial & Spinal A & Facial & Spinal A & Facial \\
\hline & $3.9 \pm 1.3$ & $3.5 \pm 1.2$ & $12.2 \pm 8.3$ & $11.5 \pm 9.3$ & $30.2 \pm 19.7$ & $25.5 \pm 19.6$ & & & & \\
\hline $\begin{array}{l}\text { Median } \\
\text { (range) }\end{array}$ & $\begin{array}{l}4 \\
(2-6)\end{array}$ & $\begin{array}{l}3.5 \\
(2-5)\end{array}$ & $\begin{array}{l}10 \\
(5-38)\end{array}$ & $\begin{array}{l}9 \\
(4-40)\end{array}$ & $\begin{array}{l}28 \\
(9-55)\end{array}$ & $\begin{array}{l}23 \\
(5-52)\end{array}$ & 40.14 & 34.3 & $<0.001 * *$ & $<0.001 * *$ \\
\hline
\end{tabular}

$P<0.001$ : Significant, **: Significant

Table (8): Comparison between patients who developed respiratory failure and those who didn't according to severity of decrement response $(\%)$ of both spinal accessory (spinal $A$ ) and facial nerve as assessed by repetitive nerve stimulation (RNS) at 4th day of admission

\begin{tabular}{|c|c|c|c|c|c|c|}
\hline \multirow{2}{*}{ Groups } & \multicolumn{2}{|c|}{ Mean \pm SD } & \multicolumn{2}{|c|}{ t } & \multicolumn{2}{|c|}{ P-value } \\
\cline { 2 - 6 } & Spinal A & Facial & $\begin{array}{c}\text { Spinal } \\
\text { A }\end{array}$ & Facial & Spinal A & Facial \\
\hline \multirow{2}{*}{$\begin{array}{c}\text { Severity of decrement } \\
\text { response (\%) }\end{array}$} & $\begin{array}{c}\text { Patients who developed } \\
\text { respiratory failure(n=8) }\end{array}$ & $43.1 \pm 5.8$ & $42.6 \pm 5.4$ & \multirow{2}{*}{21.5} & 24.3 & $<0.001 * *$ \\
\cline { 2 - 7 } & $\begin{array}{c}\text { Patients who didn't develop } \\
\text { respiratory failure(n=47) }\end{array}$ & $6.8 \pm 3.9$ & $6.4 \pm 3.6$ & $<0.001 * *$ \\
\hline
\end{tabular}

$P<0.001$ : Significant, **: Significant

Table (9): correlation between serum creatine phosphokinase(CPK)(IU/L) level and severity of decrement response (\%)of both spinal accessory (spinal $A$ ) and facial nerve in patients with organophosphorus poisoning (OP)at 4th day of poisoning by Spearman correlation test.

\begin{tabular}{|l|c|c|c|c|}
\hline \multirow{2}{*}{} & \multicolumn{3}{|c|}{ Serum creatine phosphokinase(CPK)(IU/L) } \\
\cline { 2 - 5 } & \multicolumn{2}{|c|}{ r } & \multicolumn{2}{|c|}{ P-value } \\
\cline { 2 - 5 } & Spinal A & Facial & Spinal A & Facial \\
\hline Severity of decrement response (\%) & 0.98 & 0.93 & $<0.001 * *$ & $<0.001 * *$ \\
\hline
\end{tabular}

IU/L: International unit per liter. $r$ : Correlation coefficient P<0.001: Significant, . **: Significant

Table (10): correlation between serum Lactate dehydrogenase level (IU/L) and severity of decrement response (\%) of both spinal accessory (spinal A) and facial nerve in patients with organophosphorus poisoning (OP) at $4^{\text {th }}$ day of poisoning by Spearman correlation test.

\begin{tabular}{|l|c|c|c|c|}
\hline \multirow{2}{*}{} & \multicolumn{3}{|c|}{ serum lactate dehydrogenase level(IU/L) a } \\
\cline { 2 - 5 } & \multicolumn{2}{|c|}{$\mathrm{r}$} & \multicolumn{2}{c|}{ P-value } \\
\cline { 2 - 5 } & Spinal A & Facial & Spinal A & Facial \\
\hline severity of decrement response (\%) & 0.39 & 0.42 & 0.09 & 0.06 \\
\hline
\end{tabular}

IU/L: International unit per liter, $r$ : Correlation coefficient, $P>0.05:$ non-significant. 

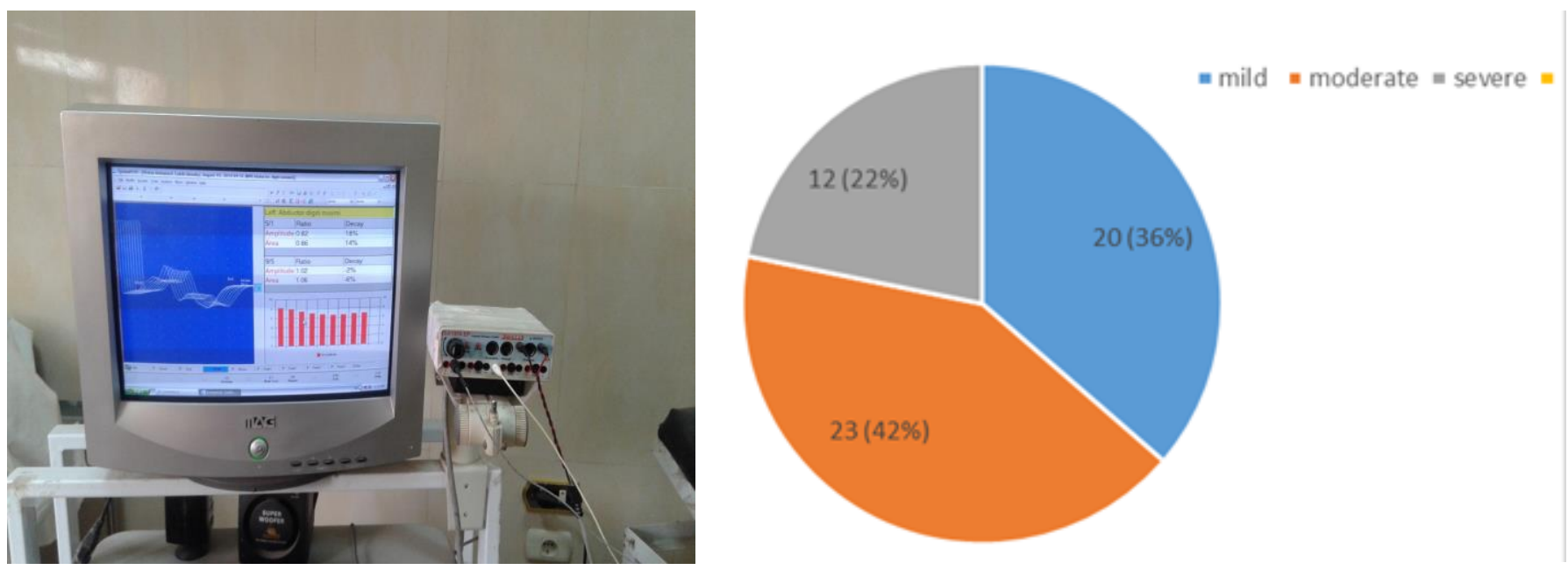

Fig. 1: Nicolet electromyography machine

Fig 2: Distribution of patients according to clinical sevirity

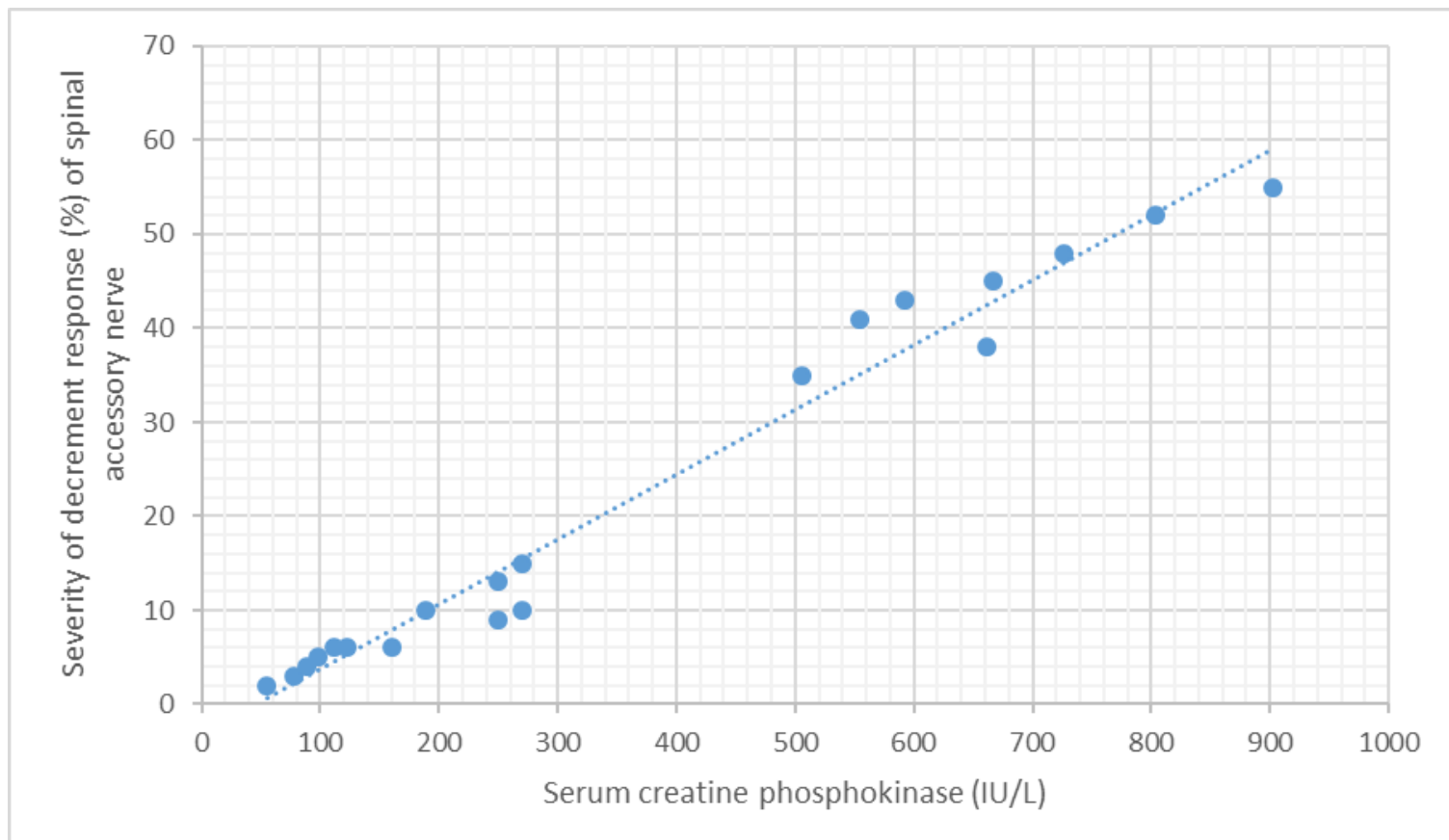

Fig.3: Correlation between serum creatine phosphokinase level and severity of decrement response (\%) of spinal accessory nerve assessed at $4^{\text {th }}$ day of poisoning. 


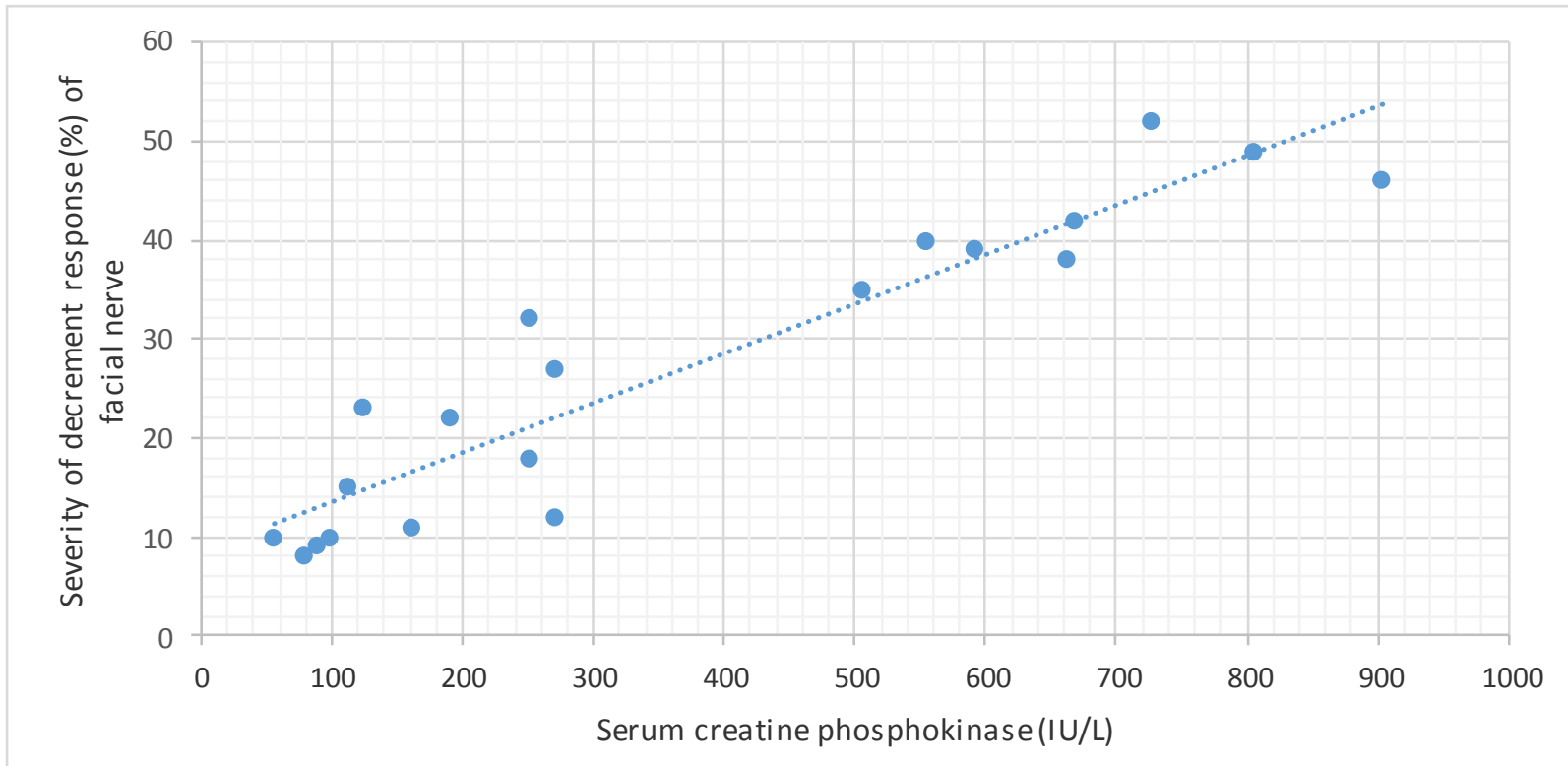

Fig.4: Correlation between serum creatine phosphokinase level and severity of decrement response (\%) of facial nerve assessed at $4^{\text {th }}$ day of poisoning

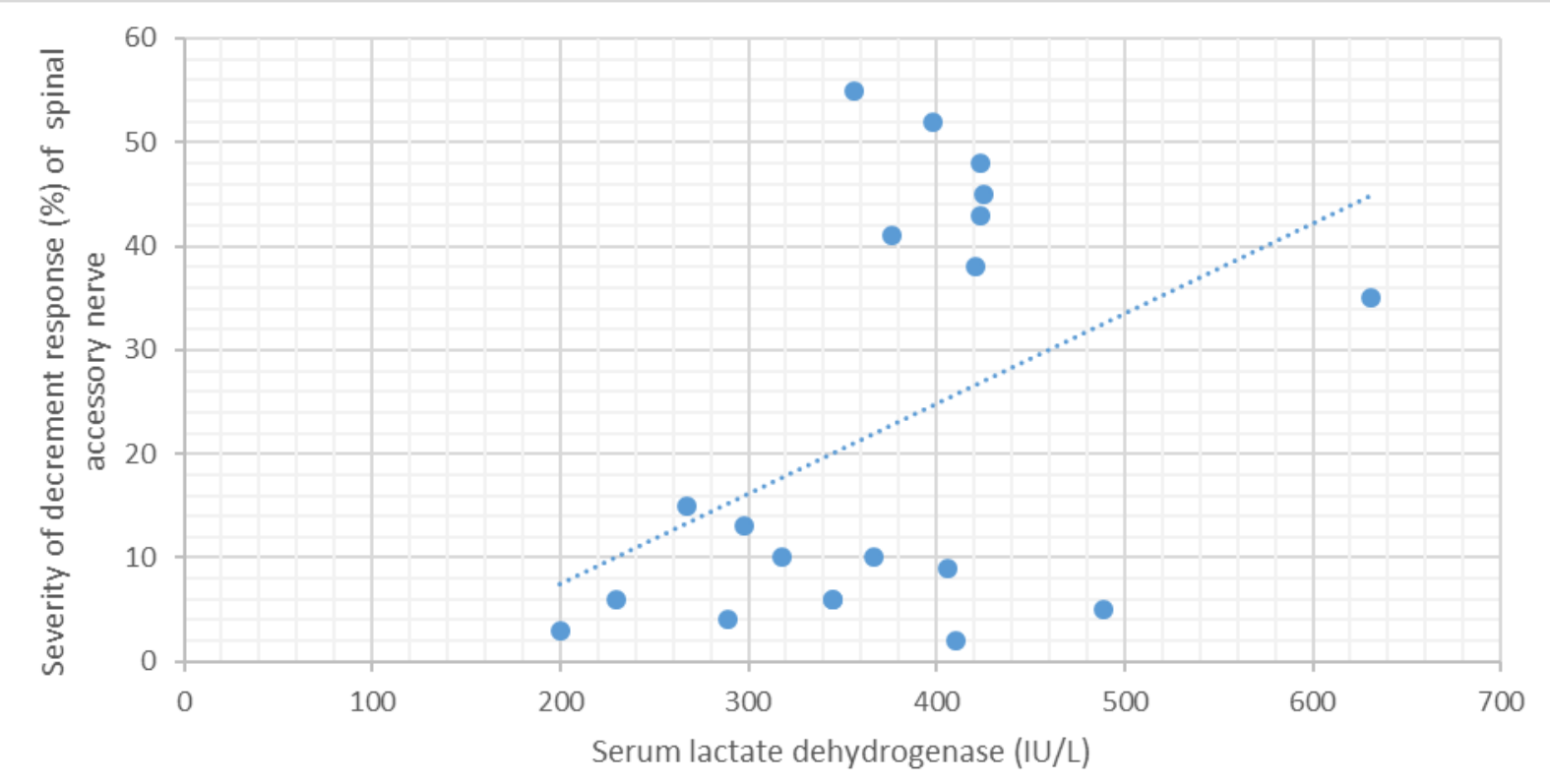

Fig. 5: Correlation between serum lactate dehydrogenase level and severity of decrement response (\%) of spinal accessory nerve assessed at $4^{\text {th }}$ day of poisoning. 


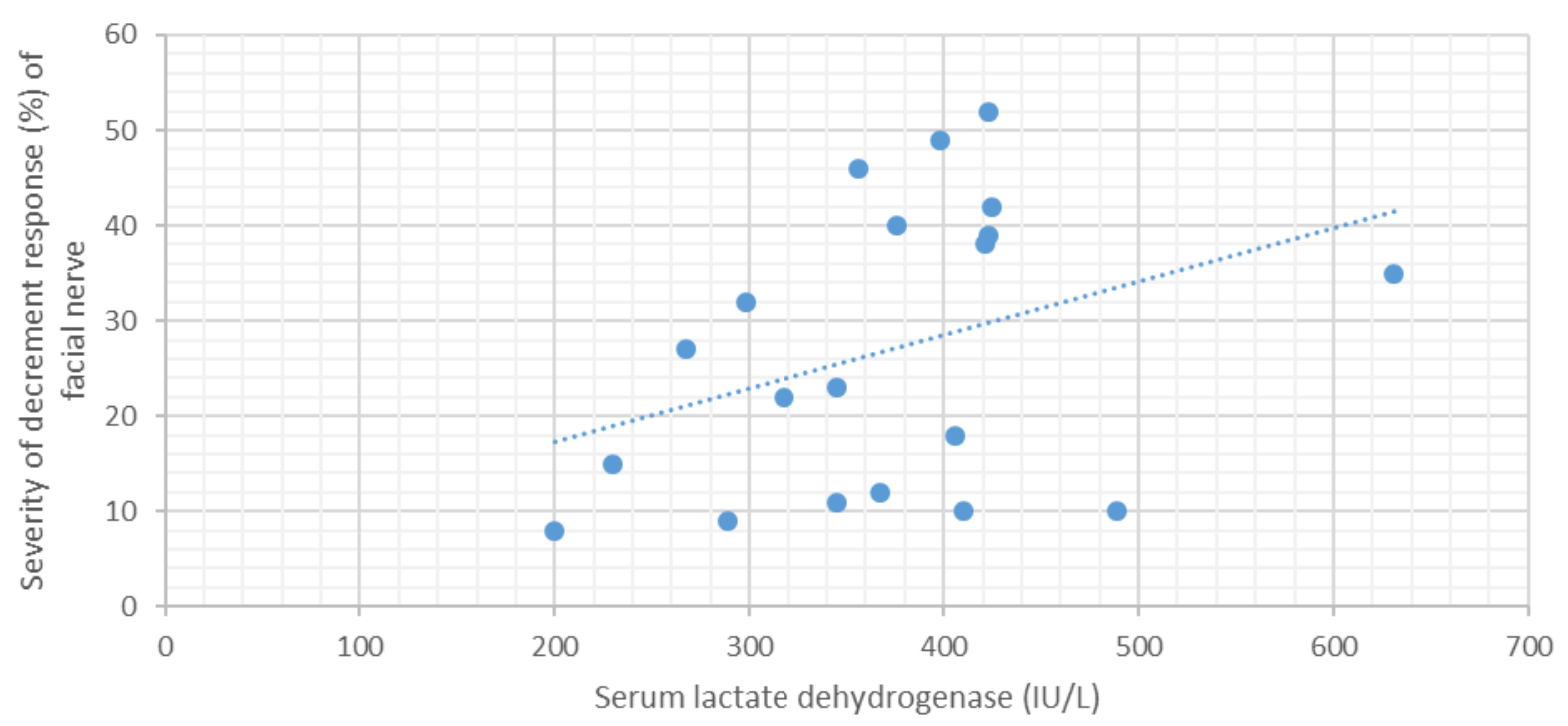

Fig. 6: Correlation between serum lactate dehydrogenase level and severity of decrement response (\%) of facial nerve assessed at $4^{\text {th }}$ day of poisoning.

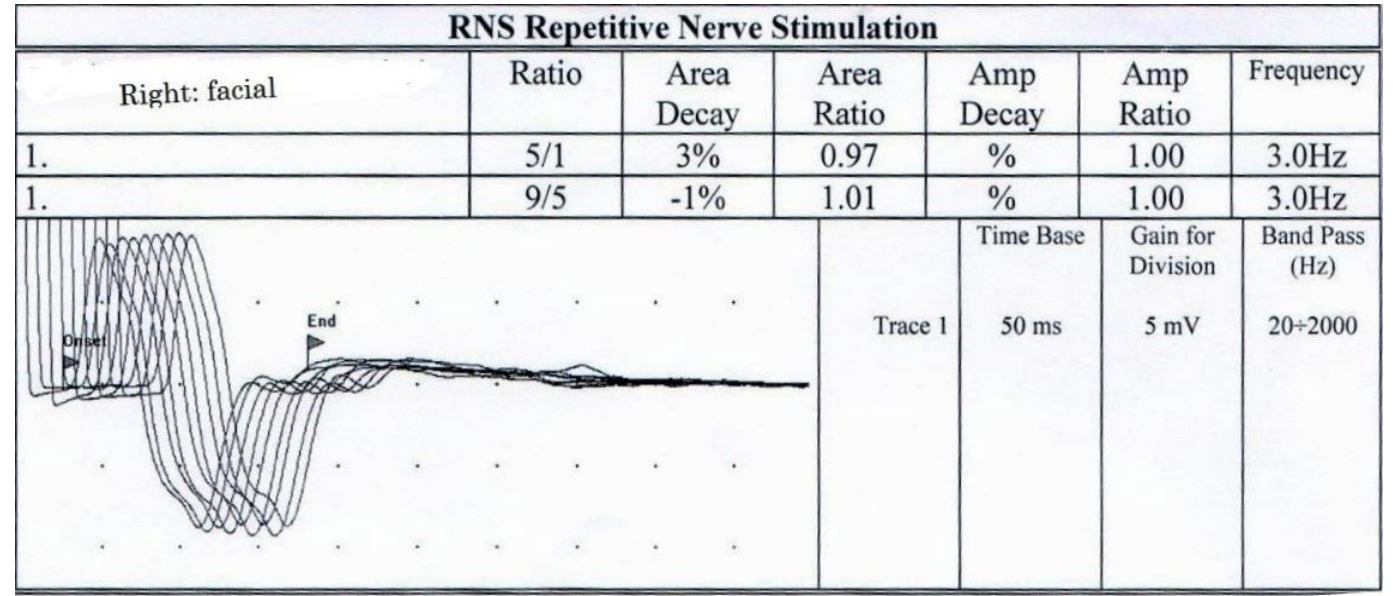

Fig. 7: Decrement response (facial nerve) in a mild case recorded by RNS $(3 \mathrm{HZ})$ at $2^{\text {nd }}$ day of poisoning (no decrement is detected)

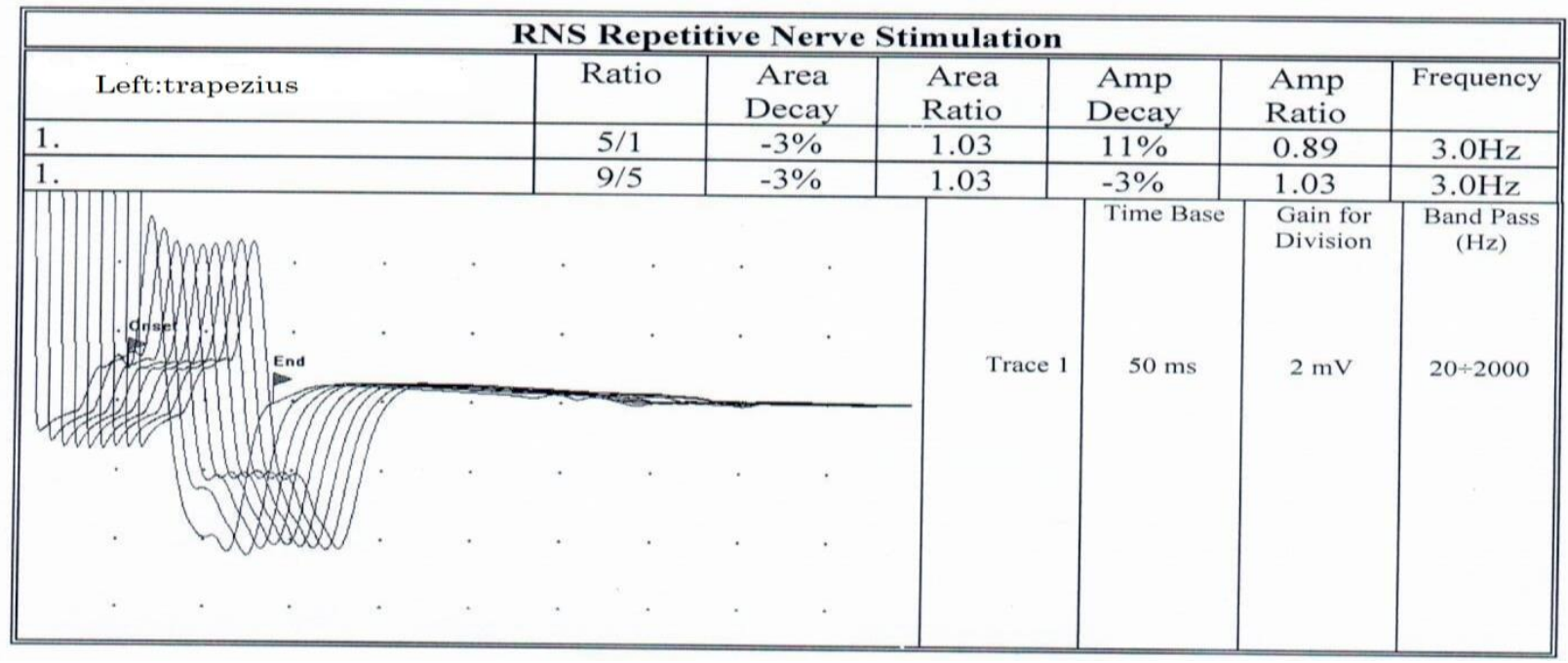

Fig. 8: Decrement response (spinal accessory nerve) in a moderate case recorded by RNS $(3 \mathrm{HZ})$ at $2^{\text {nd }}$ day of poisoning (11\% decrement). 


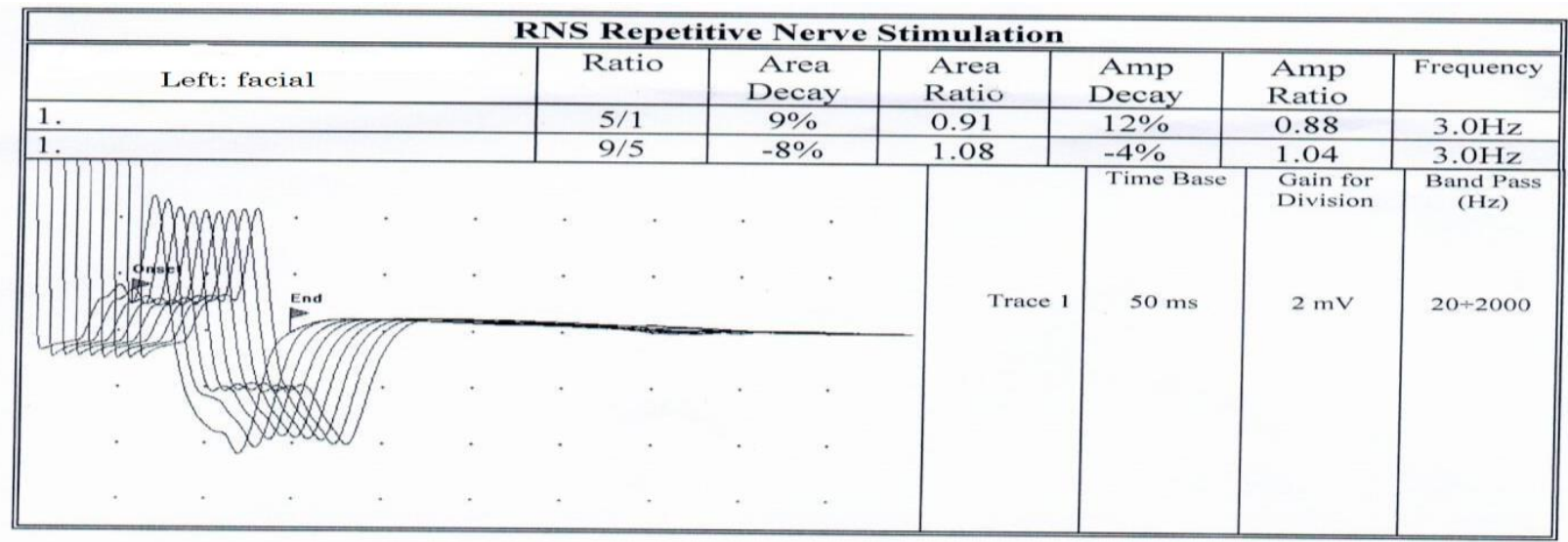

Fig.9: Decrement response (facial nerve) in a severe case recorded by RNS (3 HZ) at $2^{\text {nd }}$ day of poisoning (12\% decrement)

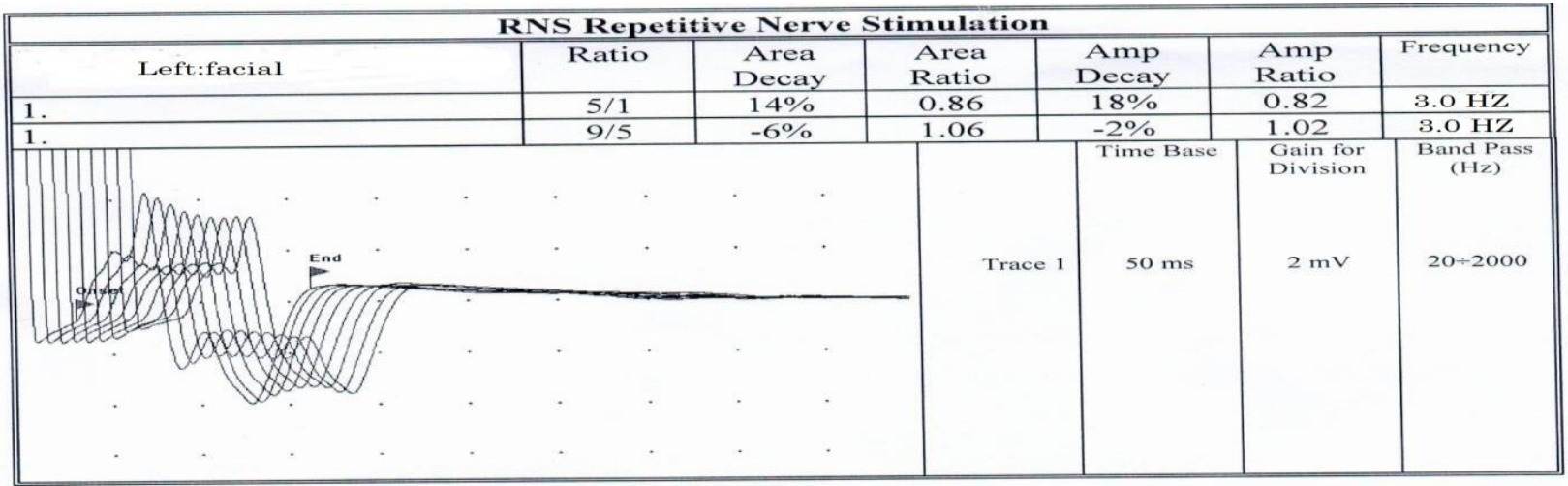

Fig. 10: Decrement response (facial nerve) in a moderate case recorded by RNS (3 HZ) at $3^{\text {rd }}$ day of poisoning (18\% decrement) .

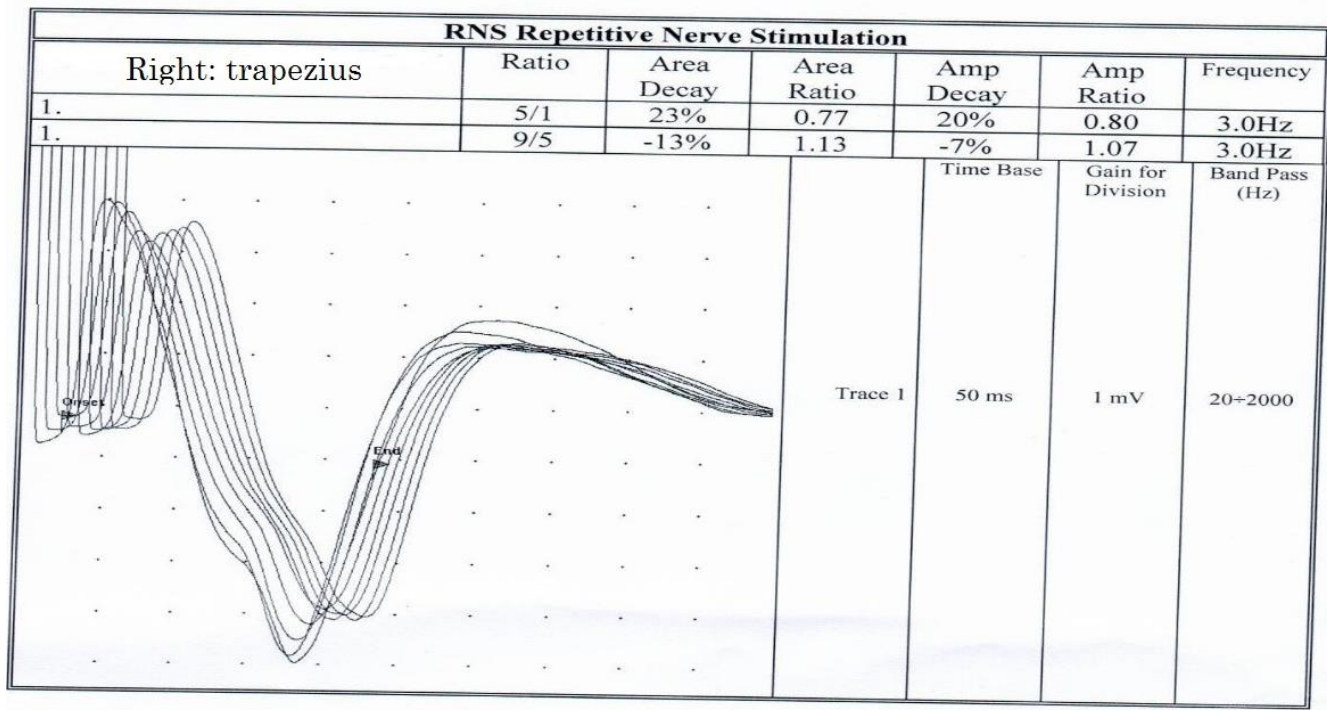

Fig. 11: Decrement response (spinal accessory nerve) in a severe case recorded by $\operatorname{RNS}(3 \mathrm{HZ})$ at $3^{\text {rd }}$ day of poisoning (20\% decrement). 


\begin{tabular}{||l|c|c|c|c|c|c|c||}
\hline \hline \multicolumn{10}{|c||}{ RNS Repetitive Nerve Stimulation } \\
\hline \hline Left: facial & Ratio & $\begin{array}{c}\text { Area } \\
\text { Decay }\end{array}$ & $\begin{array}{c}\text { Area } \\
\text { Ratio }\end{array}$ & $\begin{array}{c}\text { Amp } \\
\text { Decay }\end{array}$ & $\begin{array}{c}\text { Amp } \\
\text { Ratio }\end{array}$ & Frequency \\
\hline 1. & $5 / 1$ & $19 \%$ & 0.81 & $22 \%$ & 0.78 & $3.0 \mathrm{~Hz}$ \\
\hline 1. & $9 / 5$ & $-5 \%$ & 1.05 & $-5 \%$ & 1.05 & $3.0 \mathrm{~Hz}$ \\
\hline \\
0
\end{tabular}

Fig. 12: Decrement response (spinal accessory nerve) in a severe case recorded by RNS $(3 \mathrm{HZ})$ at $3^{\text {rd }}$ day of poisoning (22\% decrement).

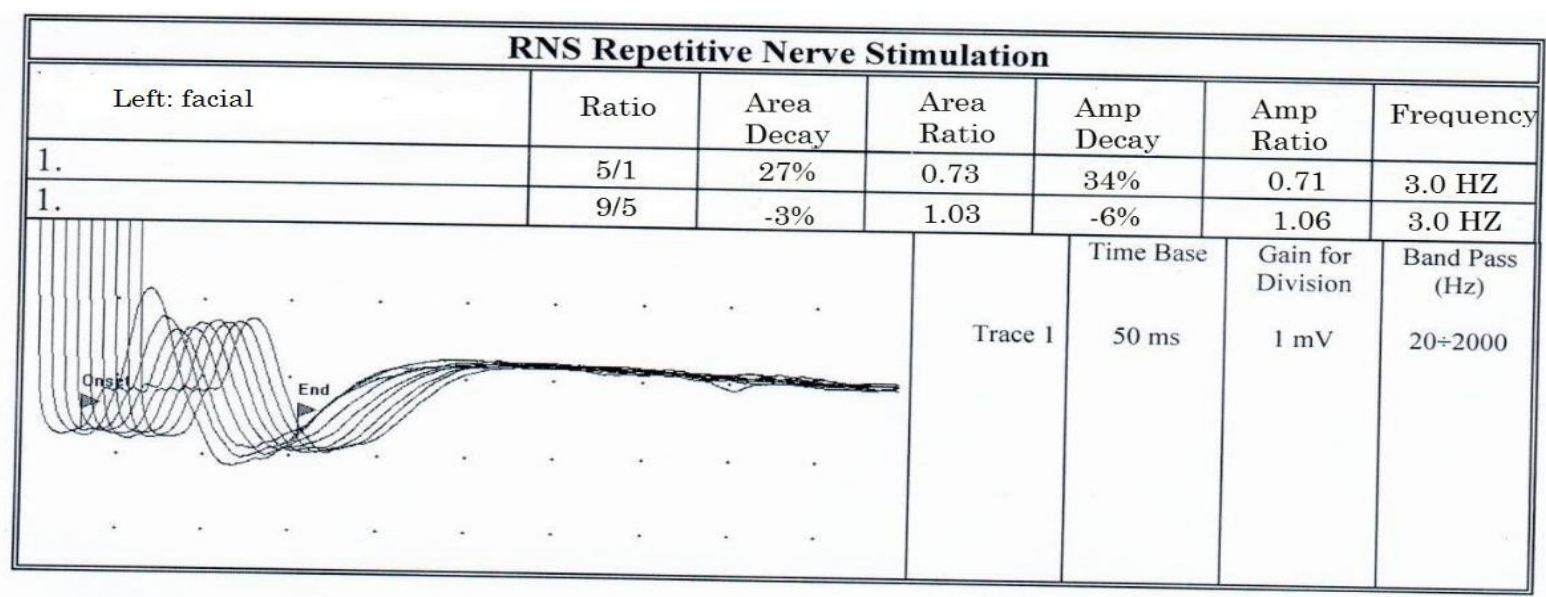

Fig. 13: Decrement response (facial nerve) in a moderate case recorded by RNS $(3 \mathrm{HZ})$ at $4^{\text {th }}$ day of poisoning $(34 \%$ decrement).

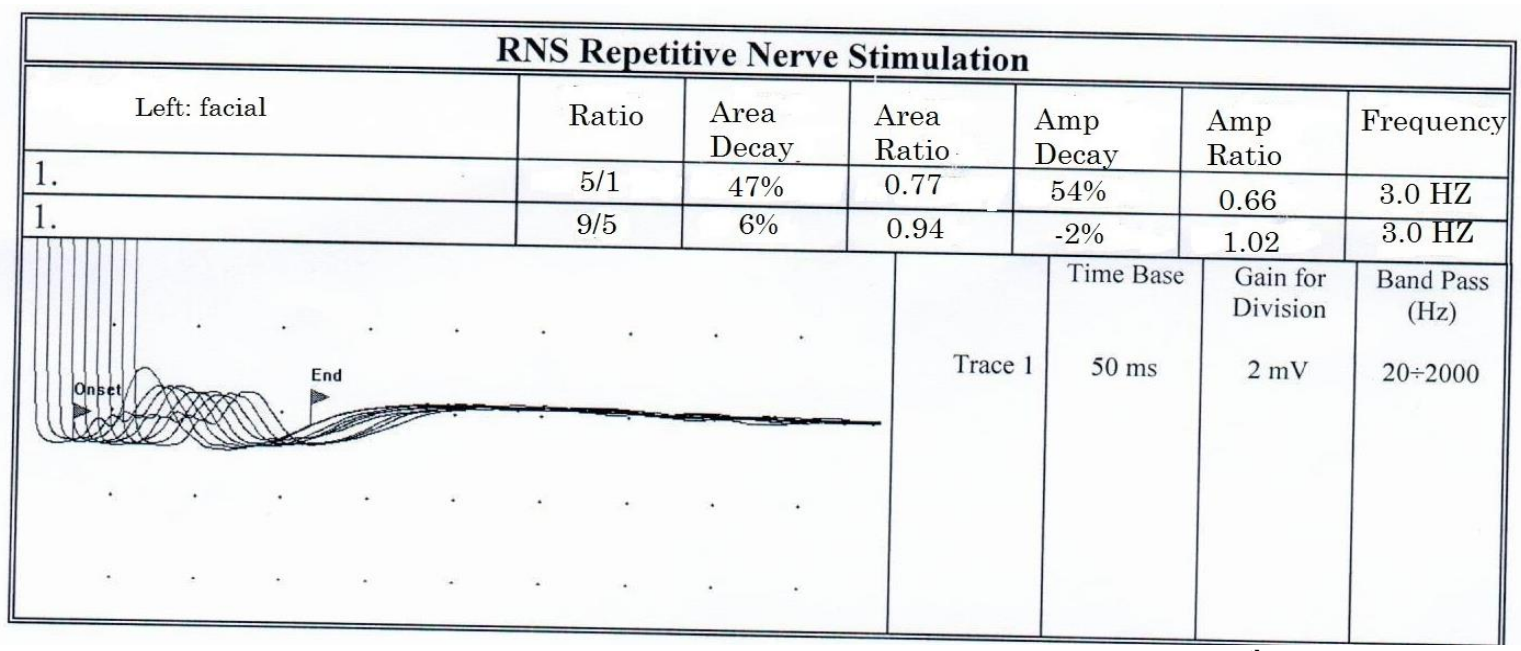

Fig.14: Decrement response (facial nerve) in a severe case recorded by RNS $(3 \mathrm{HZ})$ at $4^{\text {th }}$ day of poisoning $(54 \%$ decrement). 


\section{Discussion}

Intermediate syndrome (IMS) is a major complication associated with acute organophosphorus poisoning after recovery from cholinergic crisis. The cardinal features of this syndrome are limb weakness (proximal more than distal), facial weakness, cranial nerve palsies and respiratory muscle weakness which usually develop 2496 hours of exposure to OP insecticides (Vikram et al., 2005). The problem is in that, some of the cases which develop IMS can rapidly deteriorate and develop respiratory failure and death. Early prediction of respiratory failure will allow make correct decisions regarding such cases as to be admitted at ICU where equipment is available for emergency management of respiratory failure (Darren and Cynthia, 2007).

Some clinical studies reported electrophysiological changes by RNS in patients with OP poisoning and attributed these changes to IMS (Avasthi and Singh, 2000). Findings of other experimental and clinical studies documented that IMS is associated with rhabdomyolysis which is followed by a proportionate rise in CPK and LDH levels (Bhattacharya et al., 2011).

Taking the above mentioned studies in consideration, this study was carried out to assess the role of changes recorded by RNS and serum CPK and LDH levels in predicting respiratory failure which is the main cause of death in acute poisoning with OP insecticides.

Fifty five (55) patients diagnosed as acute organophosphorus poisoning and admitted at Poison Control Center, Zagazig University Hospitals in the period from April 2013 to June 2014 were enrolled in this study. Serum pseudocholinesterase which is measured routinely in acute OP poisoning was assessed both at time of admission and at $4^{\text {th }}$ day of poisoning. Neuromusclar transmission failure in IMS due to OP poisoning was assessed by the neurophysiological technique repetitive nerve stimulation (RNS). The decrement response was recorded and correlation with clinical severity and development of respiratory failure was studied.. Also serum CPK and LDH levels were measured for studying the probability of their use as a biochemical markers for OP poisoning severity and prediction of developing respiratory failure.

This study revealed that there was nonsignificant difference between patients who developed respiratory failure and those who didn't as regard serum pseudocholinesterase level measured at $4^{\text {th }}$ day of poisoning. These results were in parallel with that of Sen et al. (2014) who mentioned that Serum pseudocholinesterase serves as a diagnostic parameter for OP poisoning but it cannot be used as a prognostic biomarker.

The results of this study showed that there was a statistically significant increase in the mean values of serum CPK levels in patients diagnosed as severe poisoning when compared with cases of mild and moderate poisoning. This increase was both at time of admission and at the $4^{\text {th }}$ day of poisoning. In addition, there was a significant increase in serum levels of CPK among patients who developed respiratory failure when compared with those who didn't develop this serious complication.

The previous results coincided with that of Hassan and Madboliy (2013) and Sumathi et al. (2014) who stated that seum CPK is a promising prognostic indicator in OP poisoning and mentioned that, there is a strong correlation between CPK levels and severity of OP poisoning. They attributed the elevation in its level to intermediate syndrome and rhabdomyolysis associated with OP poisoning.

In a harmony with the previous results, a study carried out by Sen et al. (2014) showed that there was a statistically significant difference between survivors and non survivors from OP poisoning regarding CPK level and suggested that it can be used as a measure of prognostic significance.

On the other hand, there was non-significant difference in LDH level among patients with different clinical severities either at time of admission or 4 days following poisoning with OP. Also, comparing mean values of LDH between patients who developed respiratory failure and those who didn't, showed that there was non-significant difference between the two groups.

These results supported by Sen et al. (2014) who found that serum levels of LDH showed non significant difference between patients with acute OP poisoning who developed serious complications which end in death and those who showed complete clinical recovery. According to these results, they concluded that LDH is not a reliable indicator for prognosis and prediction of severe complications including respiratory failure.

The increase in CPK but not in LDH serum levels in acute OP poisoning can be explained by Efstratiadis et al. (2007) who stated that CPK is more reliable and sensitive indicator of muscle injury than LDH and this support the experimental studies which proved that rhabdomyonecrosis occur in animals after poisoning by OP poisoning (Vanneste and Lison, 1993).

Regarding neurophysiological assessment by RNS, patients who were diagnosed as severe poisoning at time of admission showed significant increase in the severity of decrement response throughout the period of assessment (i.e at $2^{\text {nd }}$, 3rd and $4^{\text {th }}$ day following poisoning) when compared with patients who were diagnosed as mild and moderate poisoning. When the values of decrement response were compared between patients who developed respiratory failure and those who didn't at the end of the study, it was found that cases who developed respiratory failure showed a significant increase in the mean of decrement response severity. 
Consistent with the previously mentioned findings, a study conducted by Pradeepa et al. (2008) revealed a series of electrophysiological changes in the form of decrement response recorded by RNS in patients with acute OP poisoning. They stated that these changes resolved over time in most cases but in the most severe cases, the severity of decrement response was increasing and finally ended in respiratory failure.

The mechanism of electrophysiological changes (decrement response) recorded by RNS was explained by Poojara et al. (2003) who mentioned that IMS could be due to a conformational change in the acetylcholine receptor altering the depolarization neuromuscular block to a non-depolarization block. Consistent with this mechanism, Javawardane et al. (2009) stated that, neuromuscular transmission failure observed in IMS is caused by presynaptic feedback which may reduce acetylcholine release and postsynaptic receptor desensitization.

\section{Conclusion}

It is concluded from this study that severity of decrement response recorded by RNS and serum CPK level can help in identifying the patients with acute OP poisoning who are at a high risk of developing respiratory failure, hence, they can be used as early predictors of this serious complication. So, it's recommended to use them especially in patients who are clinically diagnosed as severe OP poisoning at time of admission to decrease morbidity and mortality. On the other hand, this study revealed that serum LDH had no correlation with development of respiratory failure in OP poisoning and can not be used as a predictor of this complication .

\section{References}

Aaron CK and Howland, MA (2006): Insecticides: organophosphates and carbamates. In: Goldfrank Toxicologic Emergencies, Goldfrank, L. R., Lewin, N. A., et al., (eds)8th edition, Appleton\&Lange, Stanford. pp. 1429-48.

Abdollahi M and Karami-Mohajeri S (2012): A comprehensive review on experimental and clinical findings in intermediate syndrome caused by organophosphate poisoning. Toxicol. Appl. Pharmacol. 258(3):309-14.

Agarwal S, Bhatnagar V, Venkaiah K et al., (2006): Impairment in Clinical Indices in Acute Organophosphate Insecticide Poisoning Patients in India. The Internet J of Toxicol. 4(1).

Avasthi G and Singh G (2000): Serial neuroelectrophysiological studies in acute organophosphate poisoning:correlation with clinical findings, serum cholinesterase levels and atropine dosages. J Assoc. Physicians India. 48:794-799.
Basnyat B (2000): Organophosphate poisoning: the importance of the intermediate syndrome. J. Inst. Med. 22:248-250.

Bhattacharya K, Phaujdar S, Sarkar R et al., (2011): Serum creatine phosphokinase: A probable marker of severity in organophosphorus poisoning. Toxicol. Int. 18:117-23.

Cherian AM, Peter JV and Thomas K (1997): Effectivness of P2AM(PAM-pralidoxime)in the treatment of Organophosphorus poisoning. A randomized double blind placebo controlled trial. J. Assoc. Physic. 45: 22-24.

Darren MR and Cynthia KA (2007): Managing acute Organophosphorus pesticide poisoning. $\mathrm{Br}$. Med. J. 334:629-634.

De Bleecker JL (1995): The intermediate syndrome in organophosphate poisoning: an overview of experimental and clinical observations. Clin. Toxicol. 33: 683-686.

Eddleston M, Eyer P, Worek F et al., (2005): Differences between organophosphorus insecticides in human self-poisoning: a prospective cohort study. Lancet. 366:14521459

Efstratiadis G, Voulgaridou A, Nikiforou D et al., (2007): Rhabdomyolysis updated. Hippokratia.11(3): 129-137.

El-Sherbini AF and Fahmy SI (1983): Determining simple parameters for social classifications for health research. Bull. High Inst. Public Health. 13(5):95-108.

Hassan NA and Madboly AG (2013): Correlation between serum creatine phosphokinase and severity of acute organophosphorus poisoning: A prospective clinical study (2012-2013). J. Environ. Sci. Toxicol. Food Technol. 24:18-29.

Hsiao JF, Ning HC, Gu PW et al., (2008): Clinical role of recurrently elevated creatine kinase type 1 . J. Clin. Lab. Anal. 22:186-191.

Javawardane P, Dawson A, Weerasinghe V et al., (2008): The spectrum of intermediate syndrome following acute organophosphate poisoning: a prospective cohort study from Sri Lanka. PLoS. Med. 5: 1143-1153.

Javawardane P, Senanayake K and Dawson A (2009): Electrophysiological correlates of intermediate syndrome following acute organophosphate poisoning. Clin. Toxicol. (Phila). 47(3):193-205.

John M, Oommen A and Zachariah A (2003): Muscle injury in organophosphorous poisoning and its role in the development of intermediate syndrome. Neurotoxicol. 24(1): 43-53. 
Journal of Pharmaceutical and Biomedical Sciences (JPBMS), Vol. 17, Issue 17

Karalliedde L, Baker D and Marrs T (2006): Organophosphate-induced intermediate syndrome: aetiology and relationships with myopathy. Toxicol. Rev. 25: 1-14.

Kavya ST, Srinivas V and Madhumati R (2012): Clinical Profile of patients with Organophosphorus Poisoning in an Intensive Care Unit in a tertiary hospital. Int. J. clin. Cases Invest. Volume 4 (3): 24-31.

Lee P and Tai DY (2001): Clinical features of patients with acute organophosphate poisoning requiring intensive care. Intensive Care Med.27:694-9.

Magalhaes ME (2005): Mechanisms of rhabdomyolysis with statins. Arq. Bras. Cardiol. 85(5):42-44.

Makwava P, Odedara R and Shah Harsh D (2012): Acute Organophosphorus Poisoning And Clinical Admission Score Association Among Patients Admitted In Emergency Ward Of A Tertiary Teaching Hospital Of Medical College. J. Pharmaceut. Biomed. Sci. 17(17):1-5.

Michael E, Fahim M, James O et al., (2006): Respiratory Failure in Acute Organophosphorus Pesticide Self-Poisoning. Q. J. Med. 99(8): 513-522.

Mills K (2005): Specialised electromyography and nerve conduction studies. J. Neurol. Neurosurg. Psychiatry. 76:36-40

Morgenstern S, Flor R, Kessler G et al., (1965): Automated determination of NAD-coupled enzymes, determination of lactic dehydrogenase. Anal. Biochem. 13:149-161.

Norusis MJ (1997): Statistical package for social science (SPSS) base 8.0 for windows users guide. Chicago, IG, SPSS.

Paulo J, Juliano G, Claudia S et al., (2010): An electrophysiological study of the intermediate syndrome of organophosphate poisoning. J. Clin. Neurosci.17(19):1217-1219.

Poojara L, Vasudevan D, Arun K et al., (2003): Organophosphate poisoning: Diagnosis of intermediate syndrome. Indian J. Crit. Care Med. 7(2): 94-102.

Pradeepa J, Andrew H, Vajira W et al., (2008): The Spectrum of Intermediate Syndrome Following Acute Organophosphate Poisoning: A Prospective Cohort Study from Sri Lanka. LoS. Med. 5(7): e147.
Pradeepa J, Nimal S, Nick B et al., (2012): Electrophysiological correlates of respiratory failure in acute organophosphate poisoning: Evidence for differential roles of muscarinic and nicotinic stimulation. Clin. Toxicol. (Phila). 50(4): 250-253.

Rosalki SB (1967): An improved procedure for serum creatine phosphokinase determination. J. Lab. Clin. Med. 69:696-05.

Sen R, Nayak J and Khadanga S (2014): Study of serum cholinesterase, $\mathrm{CPK}$ and $\mathrm{LDH}$ as prognostic biomarkers in Organophosphorus Poisoning. Int. J. Med. Res. Rev. 2(3):185-189.

Senanayake N, De Silva HJ and Karalliedde LA (1993): scale to assess severity in organophosphorus intoxication: POP scale. Hum. Exp. Toxicol. 12:297-299.

Singh g, Avasthi G and Mahaja R (1998): Neurophysiologic monitoring of pharmacologic manipulation in acute Organophosphorus poisoning. The effect of pralidoxime magnesium sulphate and pancuronium. EEG and clin. neurophysiol. 107:140-148.

Stilberg E and Sanders D (1981): Electrophysiological tests of neuromuscular transmission, In: Clinical Neurophysiology, Sadlberg, E., Young RR(eds), London, Butteworths. Ch 17. pp. 88-116.

Sumathi ME, Harish S, Shashidhar KN et al., (2014): Prognostic significance of various biochemical parameters in acute organophosphorus poisoning. Toxicol. Int. 21(2): 167-171.

Vanneste Y and Lison D (1993): Biochemical changes associated with muscle fibre necrosis after experimental organophosphate poisoning. Hum. Exp Toxicol. 12(5):365-70.

Vikram P, Arun M, Mohan K et al., (2005): Intermediate syndrome in organophosphorus poisoning. J. Ind. Acad. Forensic Med. 27(1): 971-973.

Waber H (1966): Kinetic calorimetric method for detection of cholinesrease. Dtsch Med Wschr, 91:1927.

Yang D, He F and Li T (2001): Repetitive nerve stimulation and stimulation single fiber electromyography studies in rats intoxicated with single or mixed insecticides. Toxicol. 161: 111-116

Yun HW, Lee JH and Cheon YJ (2012): Serial serum cholinesterase activities as a prognostic factor in organophosphate poisoned patients. J. Emerg. Med. 19(2). 


\section{الملخص العربي}

دور التحفيز المتكرر للعصب, الكرياتين فسفوكيناز و نازعة هيدروجين اللاكتات بمصل الدم فى التنبؤ المبكر للفشل التنفسى فى التسمم الحاد بالمبيدات الفسفورية العضوية

د.سماح عادل النجدى ود.ناهد شحته

ان من اخطر المضاعفات المرتبطة بالتسمم الحاد بالمبيدات الفوسفورية العضوية هو متلازمة المتوسطة وذلك نتيجة لاحتمال حدوث فشل فن التنفس.

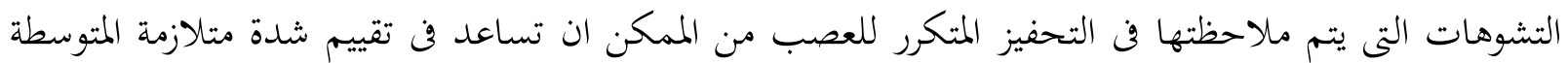

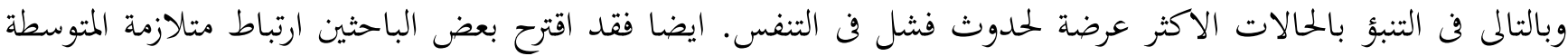

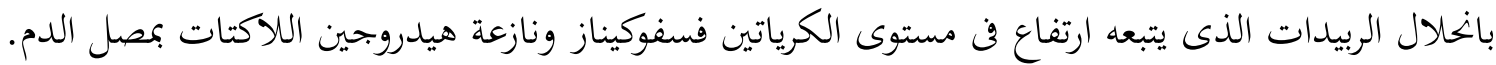

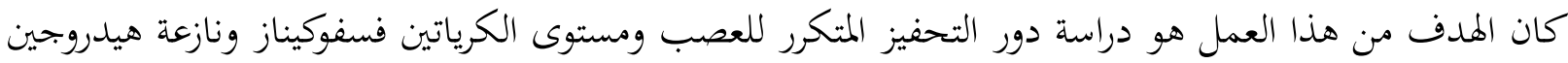

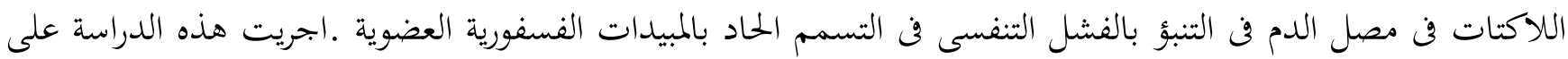

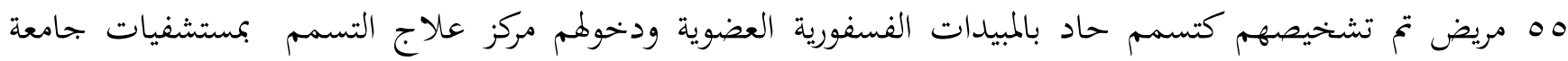

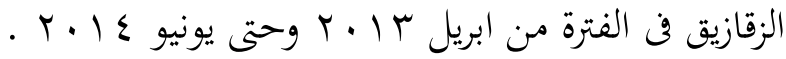

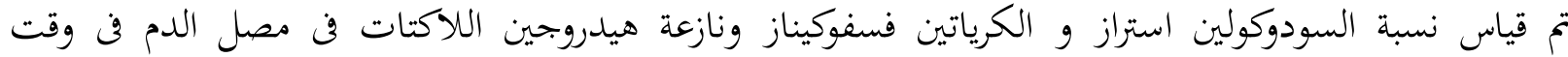

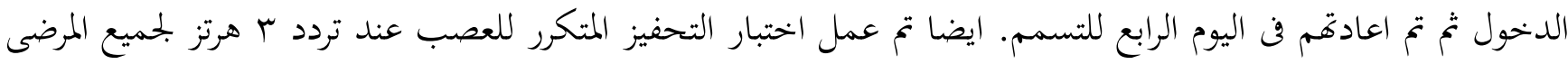
في اليوم الثانى والثالث والرابع للتسمم (الفترة المتوقعة لمتلازمة المتوسطة).

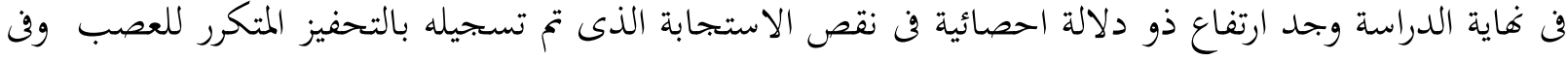

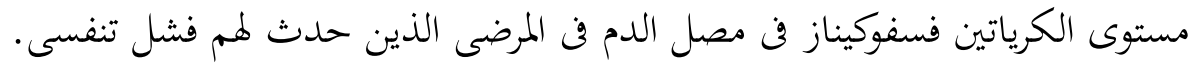

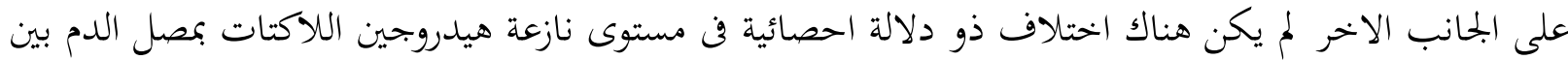

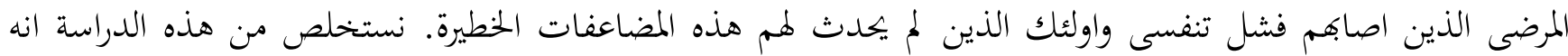

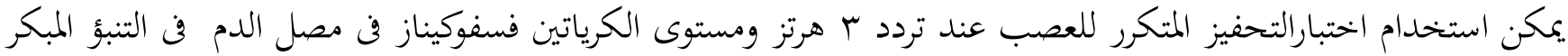

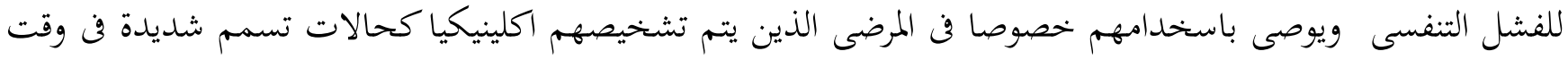

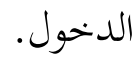

